\title{
Loads of road vehicles during piggyback transportation
}

\author{
Aleksandr Tsyganov ${ }^{1, *}$ \\ ${ }^{1}$ Nosov Magnitogorsk State Technical University, Magnitogorsk, Russia
}

\begin{abstract}
The impact of rail transportation on road vehicles that are placed in flatcars is considered in the article. The features of piggyback transportation and the dynamic forces acting on road vehicles in railway rolling stock are determined. The change dependences of the values of dynamic forces for different masses of road vehicles in the longitudinal and transverse directions are established. It is concluded that road vehicles that are used in regular piggyback transportation will experience significant dynamic loads of structural elements, which requires monitoring of their technical condition. Consequently, the infrastructure of piggyback terminals that load and unload road vehicles onto railway rolling stock should include the availability of automobile service facilities.
\end{abstract}

\section{Introduction}

The growth of foreign trade between the countries of Europe and Asia [1] and the increase in the share of Asian countries [2] in total world trade determine the need to accelerate integration processes, develop international transport corridors and equip them with modern technological equipment to ensure the flow of goods. The transport system of Russia claims to promote cargo flows through its territory within the framework of the project «Silk Road Economic Belt» [3]. The solution of these tasks can be achieved by organizing multimodal and intermodal transport. The variety of these transport is piggyback service [4]. This technology has such advantages as: improving the transportation quality of general cargo $[5,6]$, reducing transportation costs $[7,8]$, reducing the negative impact of transport on the environment $[9,10]$, etc.

The attempts to introduce piggyback transportation in Russia have been undertaken since the beginning of the 90s of the 20th century [11]. The most important tasks that have not yet been fully resolved include: the formation of a terminal infrastructure network and a fleet of specialized railway rolling stock, the development of regulatory documents and tariff policies, the integration of national piggyback technology with foreign transport systems [12]. Therefore, piggyback transportation in Russia was organized only at the level of pilot reforms $[4,13]$. In some cases, transportation turned out to be unsatisfactory and lead to damage to road vehicles [11]. In this regard, the task of studying the interaction of the elements of the «road vehicle - flatcar» system and studying the impact of rail transportation on road vehicles are on the front burner. The determination of dynamic shock

\footnotetext{
* Corresponding author: tsyganov.sm@mail.ru
} 
loads acting on road vehicles during their rail transportation will allow to evaluate the conditions of their operation activity and set up a maintenance operation and repair program for piggyback transportation.

\section{Literary review}

A number of studies are devoted to solving the problems of the interaction of railway rolling stock and road vehicles during the piggyback transportation. A review of scientific works allows us to identify several main subject areas of research:

- generalization - the literature reviews and implementation of piggyback transportation practice [4, 11, 14-17];

- technologies - the analysis of existing multimodal and intermodal technologies $[8,16$, 18];

- infrastructure - the development of infrastructure, terminals and transport network [19-21];

- ecology and sustainable development - the assessment of the piggyback transportation impact on the environment [9, 10, 22, 23];

- economy - the assessment of the developing piggyback transportation costs, their competitiveness, investments [7, 24];

- interaction - the mutual influence of railway cars and road vehicles, the calculation of the fatigue endurance of their load-bearing constructions [25-28].

Despite the availability of work devoted to solving the problems of improving the efficiency and quality of piggyback transportation, there is currently no comprehensive assessment of the impact of rail transportation on road vehicles placed in railway rolling stock during piggyback transportation.

\section{Determining the conditions for the transport of road vehicles in flatcars}

The organization of regular piggyback traffic creates a new form of road vehicles operation that are constantly involved in them. Road vehicles are transported by rail for a significant part of their operating time. This significantly reduces the overhaul and other technical and operational performance indicators. And at the same time, they are experienced by shock dynamic loads at the stage of moving along the railways, comparable with the movement on the roads. The frequency of car maintenance and repair is mainly based on time between overhaul. As a result, the realization of maintenance service of overhaul does not adequately match the actual operating conditions and may impair the maintenance of road vehicles in a technically sound state.

Transportation of road vehicles on the territory of Russia by rail is regulated by a number of documents [29-31]. They provide conditions, as well as methods of allocation and fastening the road vehicle in a flatcar. The main conditions for road vehicles are the critical mass, the surface of area exposed to wind load, the height of gravity center, the number of tiers in height, the position depending on the surface of the flatcar floor, fasteners, structural elements used for fixing, loading schemes. Basically, the listed conditions have normalized values.

It is determined that dynamic forces act on a road vehicle in the process of railway transportation. As a result, translational movement, tipping over or rolling of a flatcar may occur with it. The forces that are taken into account during placing and fixing road vehicles in a flatcar are given in Table 1. 
Table 1. Dynamic forces acting on a road vehicle [32]

\begin{tabular}{|l|l|}
\hline \multicolumn{1}{|c|}{ Names } & \multicolumn{1}{c|}{ Characteristic } \\
\hline $\begin{array}{l}\text { longitudinal inertial } \\
\text { force }\end{array}$ & $\begin{array}{l}\text { it occurs when the speed of movement of a railway carriage } \\
\text { changes (start of movement, acceleration, braking, collision } \\
\text { of cars) }\end{array}$ \\
\hline $\begin{array}{l}\text { transverse inertial } \\
\text { force }\end{array}$ & $\begin{array}{l}\text { it occurs when the direction of movement changes (the } \\
\text { passage of curves, turnouts), as well as during movement due } \\
\text { to the interaction of the railway track and the flatcar (wobble, } \\
\text { transverse and lateral rolling of the car) }\end{array}$ \\
\hline vertical inertial force & $\begin{array}{l}\text { it occurs during movement (fluctuations in bouncing and } \\
\text { pitching of a car, wheel bumps on rails at the joints) }\end{array}$ \\
\hline wind load & $\begin{array}{l}\text { it occurs when a flatcar moves and acts on parts of a unit of } \\
\text { equipment protruding beyond the wagon in the direction } \\
\text { across the path }\end{array}$ \\
\hline force of friction & $\begin{array}{l}\text { it occurs between the supporting surfaces of the unit of } \\
\text { technology and the floor of the body of a railway carriage. } \\
\text { The force of friction keeps a unit of technology from possible } \\
\text { movements in the back of a railway carriage }\end{array}$ \\
\hline
\end{tabular}

\section{Calculation of the load acting on the structural elements of a road vehicle}

The stabilization of the road vehicle position in the back of a flatcar is ensured by fasteners, for example, tension wires and wheel chocks (Fig. 1). Dynamic forces act on certain structural elements of a road vehicle through fasteners during transportation. Stretch marks transfer loads to towing hooks, hinges, axle shafts of axles, chassis, technological holes of frames, as well as other fastening parts. The load is transmitted directly to the wheels through the wheel chocks.

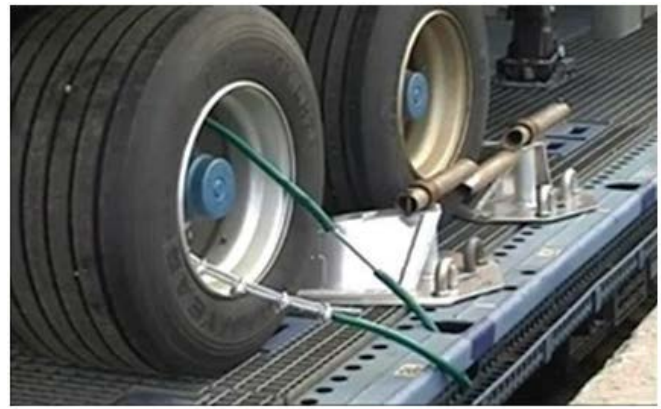

Fig. 1. Piggyback fasteners [13].

In accordance with the methodology [29], the calculation of the dynamic forces values acting on the structural elements of a conventional road vehicle, placed in flatcar and secured by two means of attachment - tension wire s and wheel chocks. It should be noted that this technique does not contain an exact indication of the shared distribution of efforts attributable to each type of fasteners when they are used together. Therefore, the limitations of efforts on the fasteners together with their characteristics were set in the calculations. An example of the result of calculating the loads acting on the elements of a road vehicle weighing 24 tons is presented in Table 2. 
Table 2. The calculated values of the dynamic forces acting on the structural elements of a road vehicle

\begin{tabular}{|c|c|c|c|}
\hline \multirow{2}{*}{ Fastener } & Structural element & \multicolumn{2}{|c|}{$\begin{array}{c}\text { The load acting on the structural } \\
\text { element in the corresponding } \\
\text { direction, } \mathrm{t}\end{array}$} \\
\cline { 3 - 4 } & & longitudinal & transverse \\
\hline tension wire & $\begin{array}{c}\text { recovery point, loop, axle } \\
\text { shaft, chassis, technological } \\
\text { hole of the frame, etc. }\end{array}$ & $2.90 \div 3.92$ & $1.28 \div 3.92$ \\
\hline wheel chock & wheel & $4.16 \div 5.18$ & $0.0 \div 1.73$ \\
\hline
\end{tabular}

The dependences of changes in the values of dynamic forces acting in the longitudinal and transverse directions were established for road vehicles of various weights (in the range from 2 to 24 tons). The values of the dynamic forces attributable to the structural elements of road vehicles placed in a single flatcar with open sides and secured by two fasteners (tension wires and wheel chocks) are shown in Fig. 2.

a)

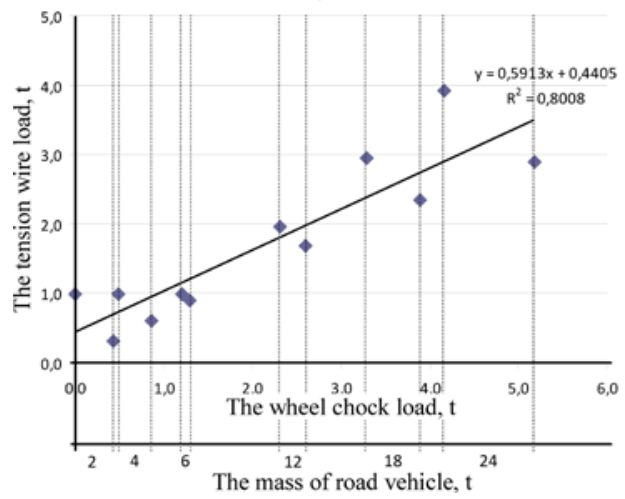

b)

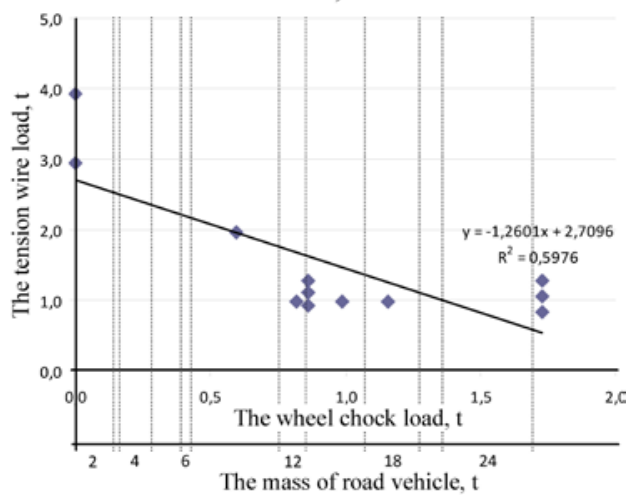

Fig. 2. The values of the dynamic forces acting on the structural elements of a road vehicle in the longitudinal (a) and transverse (b) directions.

An analysis of the load values indicates that the structural elements of road vehicles used for fastening during transportation in flatcars experience rather high loads. The main structural element exposed to dynamic loads is the undercarriage. The value of the loads is directly proportional to the mass of the road vehicle: the load of the elements increases and acts in different directions with its increase.

\section{Conclusion}

This article presents an assessment of the impact of rail transportation on road vehicles placed in railway rolling stock. The main structural element of road vehicles exposed to dynamic loads is the undercarriage. The values of dynamic forces acting on structural elements with different masses of road vehicles in the longitudinal and transverse directions are established. A significant reduction in the values of technical and operational performance indicators that determine the maintenance and repair program will be formed for road vehicles that are constantly involved in piggyback transportation. It is proposed to consider this form of operation as "passive operation activity» with the introduction of adjustments to the organization of maintenance and repair for these road vehicles. Maintenance of a technically sound state should be carried out at the automotive service 
facilities included in the infrastructure of the piggyback terminals. At that terminals loading and unloading of road vehicles on railway rolling stock is carried out.

\section{References}

1. A. Rakhmangulov, A. Sładkowski, N. Osintsev, O. Kopylova, Sustainable development of transport systems for cargo flows on the East-West direction, Transport systems and delivery of cargo on East-West routes: Studies in Systems Decision and Control, v. 156, pp. 3-69 (2018)

2. International Trade Centre, http://www.trademap.org

3. One Belt One Road Initiative, http://politics.people.com.cn/n/2014/0811/c100125439028.html

4. M. Zhuravskaya, I. Makarenko, Piggyback transportations as point of growth of logistic business JSC Russian Railways, Transport of the Urals, v. 3(38), pp. 74-79 (2013)

5. B. Wiśnicki, A. Dyrda, Analysis of the Intermodal Transport Efficiency in the Central and Eastern Europe, Naše more, v. 63(2), pp. 43-47 (2016)

6. A.V. Tsyganov, Use of the analytic hierarchy process in quality management of piggyback transportations, Reliability and Quality of Complex Systems, v. 2(26), pp. 121-129 (2019)

7. P.M. Panayides, Economic organization of intermodal transport, Transport Reviews, v. 22(4), pp. 401-414 (2002)

8. C. Li, G. Yang, X. Sun, Transshipment Equipments for Road-Rail Intermodal Transport, Advanced Materials Research, v. 1065-1069, pp. 3377-3380 (2015)

9. J. Pinto, O. Mistage, P. Bilotta, E. Helmers, Road-rail intermodal freight transport as a strategy for climate change mitigation, Environmental Development, v. 25, pp. 100110 (2018)

10. V.-G. Stinga (Cristea), Intermodal transport - a way of achieving sustainable development, Constanta Maritime University Annals, v. 22, pp. 145-148 (2014)

11. A.V. Chubukov, Organization of piggyback transportation in Russia and in the world, Izvestia of the Petersburg State University of Railway Transport, v. 2, pp. $44-54$ (2010)

12. A.V. Tsyganov, PEST Analysis of the organization piggyback transportation in Russia, Engineering Bulletin of the Don, v. 2(53), pp. 18 (2019)

13. A.N. Kryazhev, Organization of regular piggyback communication in Russia, Transport of the Russian Federation, v. 1(62), pp. 18-21 (2016)

14. K.V. Kholopov, Piggyback traffic foreign experience and development directions in Russia, Russian Export Reporter, v. 9, pp. 101-108 (2011)

15. A.V. Fedorina, A.V. Tsyganov, An integrated approach to the implementation of piggyback transportation in Russia, Modern Problems of Russian Transport Complex, v. 1(6), pp. 21-28 (2015)

16. M.Yu. Skorchenko, International experience in organizing regular piggyback service, Transportation Systems and Technology, v. 4(1), pp. 19-42 (2018)

17. P.V. Kurenkov, A.N. Kryazhev, A.V. Astaaf'ev, M.V. Kizimirov, Analysis of piggyback implementation experience in the EU and US, Vestnik of Transport, v. 5, pp. 17-22 (2016) 
18. G.V. Bubnova, O.V. Efimova, I.V. Karapetyants, Digitalization of intellectualization of logistics of intermodal and multimodal transport, MATEC Web of Conferences, v. 236(149), pp. 2013 (2018)

19. D.V. Kuzmin, V.V. Baginova, A.N. Rakhmangulov, B.A. Leuven, Forming and Developing the Controller Terminal Regional Network for Conditions of the Russia Federation, International Journal of Economic Perspectives, v. 11(2), pp. 754-763 (2017)

20. M. Mindura, Transport in trade between Europe and Asia (Warsaw: Institute of Technology, 2011)

21. J. Siroky, The Trends of Road Trailers Systems for Railways, Perner's Contacts, v. 7(4), pp. 137-151 (2012)

22. A. Rakhmangulov, A. Sladkowski, N. Osintsev, D. Muravev, Green Logistics: A System of Methods and Instruments. Part 2, Nase More, v. 65(1), pp. $49-55$ (2018)

23. M.A. Zhuravskaya, Green Logistics - Success Strategy in the Development of Modern Transport, Bulletin of the Ural State University of Railway Transport, v. 1(25), pp. 3848 (2015)

24. M.V. Kizimirov, Social and economic effect of piggyback transportation, Vestnik of Transport, v. 9, pp. 37-38 (2012)

25. A.N. Sapozhnikov, Study of the interaction of a flatcar and an semi-trailer during piggyback transportation as a dynamic system, Deposited manuscript, № 6408zhd2003 (2003)

26. M.V. Sudareva, Analysis of the dynamic performance of a flatcar for piggyback transportation, The future of Russian engineering, v. 2, pp. 170-172 (2009)

27. V.V.Kobishchanov, D.Ya. Antipin, M.V. Manueva, Assessment of the impact of taking into account the elastic properties of the suspension of a road train on the dynamic characteristics of a flatcar for piggyback transportation, Bulletin of the Bryansk State Technical University, v. 4(52), pp. 179-185 (2016)

28. G.A. Kovalev, O.N. Chislov, E.E. Suprun, Methodological features of the organization of railway piggyback transportation, Bulletin of the Rostov State University of Communications, v. 3(71), pp. 104-113 (2018)

29. Technical conditions for the placement and fixing of cargoes in wagons and containers (Moscow: Yurtrans Law Firm, 2003)

30. Technical conditions for the placement and fixing of cargoes (Appendix 3 to the Agreement on international railway freight traffic (Moscow, 2015)

31. Order from the Ministry of Transportation No. 278 «About claim of the Technical conditions for the placement and fastening of cars, road trains, trailers, semi-trailers, swap bodies in empty or loaded condition during transportation in freight cars»» (Moscow, 2017)

32. A.V. Tsyganov, Cargohandling: transport characteristics of cargoes (Moscow: INFRA-M, 2018) 